\title{
Compound odontoma in the anterior region of the mandible: clinical case report
}

\author{
Odontoma composto em região anterior de mandíbula: relato de caso clínico \\ Odontoma compuesto en la región anterior de la mandíbula: informe de um caso clínico
}

Received: 09/23/2021 | Reviewed: 09/29/2021 |Accept: 10/02/2021| Published: 10/04/2021

Eduardo Quintão Manhanini Souza

ORCID: https://orcid.org/0000-0002-5505-065X

São Paulo State University, Brazil

E-mail: eduardoquintao@hotmail.com

Vinícius Franzão Ganzaroli

ORCID: https://orcid.org/0000-0002-8590-4978

São Paulo State University, Brazil

E-mail: viníciusfganzaroli@hotmail.com

Igor Rodrigues de Almeida

ORCID: https://orcid.org/0000-0002-7945-0383

Federal University of Alfenas, Brazil

E-mail: igorrodriguesalmeida@ hotmail.com

Jéssica de Oliveira Alvarenga Freire

ORCID: https://orcid.org/0000-0002-5891-8637

São Paulo State University, Brazil

E-mail: je.oafreire@gmail.com

Luy de Abreu Costa

ORCID: https://orcid.org/0000-0003-3661-8219

São Paulo State University, Brazil

E-mail: luyabreucosta@gmail.com

Luan Felipe Toro

ORCID: https://orcid.org/0000-0002-1049-4257

São Paulo State University, Brazil

E-mail: luan.toro@unesp.b

Isabella Zacarin Guiati

ORCID: https://orcid.org/0000-0002-1194-1602

São Paulo State University, Brazil

E-mail: isabella_zacarin@hotmail.com

Daniela Ponzoni

ORCID: https://orcid.org/0000-0001-5928-0914

São Paulo State University, Brazil

E-mail: daniela.ponzoni@unesp.br

Edilson Ervolino

ORCID: https://orcid.org/0000-0003-4859-0583

São Paulo State University, Brazil

E-mail: e.ervolino@unesp.br

Carlos Eduardo Gomes do Couto Filho

ORCID: https://orcid.org/0000-0003-1522-5774

Federal University of Alfenas, Brazil

E-mail: gomesfilho@unifal-mg.edu.br

\begin{abstract}
Odontomas are classified as a malformation where epithelial and mesenchymal cells have the ability to produce dental tissues such as enamel and dentin. Of unknown etiology, they are often associated with failure of eruption of permanent teeth and / or late impaction or exfoliation of deciduous teeth. Surgical removal is the therapeutic option of choice for the treatment of this condition, since its presence can cause some intercurrences as root resorptions of the neighboring teeth. The objective of this case report is to describe a surgical approach for the removal of a composite odontoma in the anterior region of the mandible, where after a 5-year postoperative follow-up, it was possible to observe in radiographic and tomographic analyses, small images of radiopaque characteristic compatible with recurrence tumor, hypercalcification or remnant of the lesion.
\end{abstract}

Keywords: Odontoma; Tooth abnormalities; Odontogenic tumors.

\section{Resumo}

Os odontomas são classificados como uma malformação onde células epiteliais e mesenquimais tem a capacidade de produzir tecidos dentais como esmalte e dentina. De etiologia ainda não totalmente esclarecida, estão muitas vezes associados a falha na erupção de dentes permanentes e/ou impactação ou esfoliação tardia dos dentes decíduos. A 
remoção cirúrgica é a opção terapêutica de escolha para o tratamento dessa condição, uma vez que sua presença pode causar algumas intercorrências como reabsorções radiculares dos dentes vizinhos. O objetivo deste relato de caso foi descrever uma abordagem cirúrgica para a retirada de um odontoma composto na região anterior da mandíbula, onde após 5 anos de acompanhamento pós-operatório foi possível observar em análises radiográficas e tomográficas pequenas imagens de característica radiopaca compatíveis com recidiva tumoral, hipercalcificação ou remanescente da lesão.

Palavras-chave: Odontoma; Anomalias dentais; Tumores odontogênicos.

\section{Resumen}

Los odontomas se clasifican como una malformación en la que las células epiteliales y mesenquimales tienen la capacidad de producir tejidos dentales como el esmalte y la dentina. De etiología desconocida, a menudo se asocian con falla en la erupción de los dientes permanentes y / o impactación tardía o exfoliación de los dientes temporales. La extirpación quirúrgica es la opción terapéutica de elección para el tratamiento de esta patología, ya que su presencia puede provocar algunas intercurrencias como reabsorciones radiculares de los dientes vecinos. El objetivo de este caso clínico fue describir un abordaje quirúrgico para la extirpación de un odontoma compuesto en la región anterior de la mandíbula, donde luego de 5 años de seguimiento postoperatorio fue posible observar en análisis radiográficos y tomográficos, pequeñas imágenes de característica radiopaca compatible con recidiva tumoral, hipercalcificación o remanente de la lesión.

Palabras clave: Odontoma; Anomalías dentarias; Tumores odontogénicos.

\section{Introduction}

Paul Broca was the first author to use the term odontoma, in 1867 defining it as "a tumor formed by the overgrowth of transient or complete dental tissues" (Budnick., 1976). Odontomas are the most common variety of odontogenic tumors, derived from epithelial, mesenchymal or mixed cells, benign tumors consisting of enamel, dentin, cementum and pulp tissue. They develop during odontogenesis, have a slow growth and are usually asymptomatic and are usually diagnosed by routine radiographic examinations between the first and second decade of life (Matos et al., 2012; Neville et al., 2016; Silva et al., 2020).

The etiology of this condition is not yet completely elucidated, genetic factors such as mutations or the interference of a gene in the control of dental development have been suggested as well as trauma and infections infections (Jaeger et al., 2012; Raval et al., 2014; Salamanca et al., 2017). The development of odontoma is commonly associated with failure of eruption of permanent teeth, impaction or delayed exfoliation of deciduous teeth (Pacifici et al., 2015). According to the last classification of the World Health Organization in 2005, odontomas should be classified as a malformation rather than a tumor, and can be found in two different types: complex and compound (Avsever et al., 2015). Complex odontomas are malformations in which all dental tissues are present, but are in a disorganized arrangement or pattern; while composite odontoma presents malformations in which all dental tissues are represented in a pattern that is more ordered, similar to normal teeth (Nammalwar et al., 2014), and may vary in size, shape and number, which are called denticles (Silva et al., 2019).

Composite odontomas are generally found in the anterior region of the maxilla, followed by the anterior region of the mandible and correspond to about $67 \%$ of the cases diagnosed (Matos et al., 2012), while the complexes, in turn, have a higher incidence in the posterior region of the mandible, varying sizes, reaching several centimeters under impacted teeth (Kannan et al., 2013). Regardless of the case, surgical removal is the therapeutic option of choice, since the chance of recurrence is low and the prognosis is favorable.

Thus, the purpose of this case report is to describe a surgical approach for the removal of a composite odontoma located in the anterior region of the mandible associated with a deciduous canine. The objective of this technique is to preserve the maximum bone structure surrounding the lesion in order to promote a better healing and maintain the pulp vitality of the neighboring teeth, causing the least possible postoperative discomfort to the patient. 


\section{Methodology}

The present study is a descriptive qualitative case report, which brings relevant data regarding the characteristics, etiology and treatment of compound odontoma. The clinical case presented is of a 20-year-old male patient, leucoderma, presenting a compound odontoma in the anterior region of the mandible. The patient signed an informed consent form (Pereira et al., 2018).

\section{Case Report}

A 20-year-old male patient, Leucoderma, attended on the Department of Clinics and Surgery of the Faculty of Dentistry of the Federal University of Alfenas (UNIFAL-MG) reporting discomfort in the retromolar region to assess the need for third molar extraction, he was asked to perform a routine panoramic radiograph as a complementary examination. Radiographic examination revealed the presence of a fourth molar in the right maxilla of the patient, as well as the existence of a radiopaque mass with numerous calcified dentiform structures juxtaposed with the root of the left lower canine, since the permanent canine (tooth 33) was impacted in the region of the base of the mandible of the right side, surpassing the midline (Figure 1).

The patient reported not remembering to have suffered any trauma in the anterior region of the mandible, as well as demonstrated lack of knowledge of the existence of a deciduous tooth still in function. In view of this radiographic finding, the patient was instructed to perform a tomographic examination of the mandible, in order to better diagnose the morphological characteristics of the lesion, such as extension and shape. The tomographic examination revealed the presence of several denticles, with characteristics similar to normal teeth, with different size, shape and orientation (Figure 2 and Figure 3).

We then planned the surgical removal of the lesion under local anesthesia, where we chose not to remove the impacted canine. A surgical approach was performed, with a minimum of bone resection, debridement of the surgical hole, bone graft and follow-up of clinical evolution.

After the aseptic preparation with a product based on Polyvinylpyrrolidone (PVPI) in aqueous solution containing 1\% Active Iodine (Rioquímica Ltda, São Paulo, SP, Brazil), the patient underwent local anesthesia with $2 \%$ Lidocaine + Epinephrine 1:100.000 (Alphacaine 100 - New DFL, Rio de Janeiro, RJ, Brazil), the inferior and the mental alveolar nerve block was performed on both sides, as well as complementary infiltrative techniques throughout the region to be operated for homeostasis and pain control. An intrasulcular incision was performed between the teeth 35 and 42 , where a distal incision was made in $45^{\circ}$ at apical direction, for a greater flap mobility and better visualization of the bone tissue. A full-thickness flap was performed using a Molt 2-4 detachment and the bone tissue was exposed. The layer of cortical bone tissue overlying the lesion was removed with a spherical diamond drill bit in a high-speed motor under constant irrigation with sterile $0.9 \%$ saline solution (Eurofarma Laboratory AS, Ribeirão Preto, SP, Brazil) as well a chisel of Ochsenbein $\mathrm{n}{ }^{\circ} 1$ was used for careful bone resection (Figure 4).

With the aid of levers and extractors, straight and curved, the denticles were dislocated and extracted one at a time, in order to preserve as much bone tissue as possible and, also, the roots of the neighboring teeth. It was performed the dental section of the denticle of larger size and curvature, where after removal of all micro-teeth the surgical hole was debrided with Lucas curettes for enucleation of the lesion, the bone defect was filled with a synthetic bone substitute based in $\beta$ - tricalcium phosphate (Cerasorb® M, Curassan). We chose not to remove the impacted canine and consequently to follow it up, considering its location and discontinuity with the bone lesion. The suture was performed with a 4-0 resorbable yarn of Polyglactin 910 (Bioline, Anápolis GO Brazil), a continuous suture anchored to the teeth was performed in the region near the lower teeth and in the relief incision made distal the tooth 42, single stitches were made (Figure 5). 
The patient received postoperative guidelines such as resting, avoiding exposure to the sun, feeding more pasty foods and iced in the first few days and not performing physical exercises for at least a week. Prior to surgery (1 hour before) the patient was given $4 \mathrm{mg}$ of Dexamethasone, a dose that was given for a further two days at 24-hour intervals, and 0.12\% chlorhexidine mouthwash was prescribed twice daily for 7 days. For pain control Sodium Dipyrone was prescribed. There was no complication during the healing of the operated region.

In the 5-year postoperative follow-up, the radiographic examination showed bone neoformation in the place where the odontoma had previously been located, and the image of two small structures with mild central radiopacity surrounded by a narrow radiolucent zone was also observed. The tomographic examination confirmed the radiographic findings between teeth 32 and 34. These characteristics are consistent with the cortical bone that surrounded the odontoma, and the radiopaque points in its interior suggest the presence of remnant biomaterial, areas of hypercalcification, recurrence tumor, or remnant of the lesion.

From a clinical and radiographic point of view, the follow-up of the case is extremely important, and a second surgical intervention was not performed since the patient chose not to perform primary canine extractions and rehabilitative planning. However, we do not rule out the possibility of a new surgical intervention over time.

Figure 1: Initial radiographic examination.

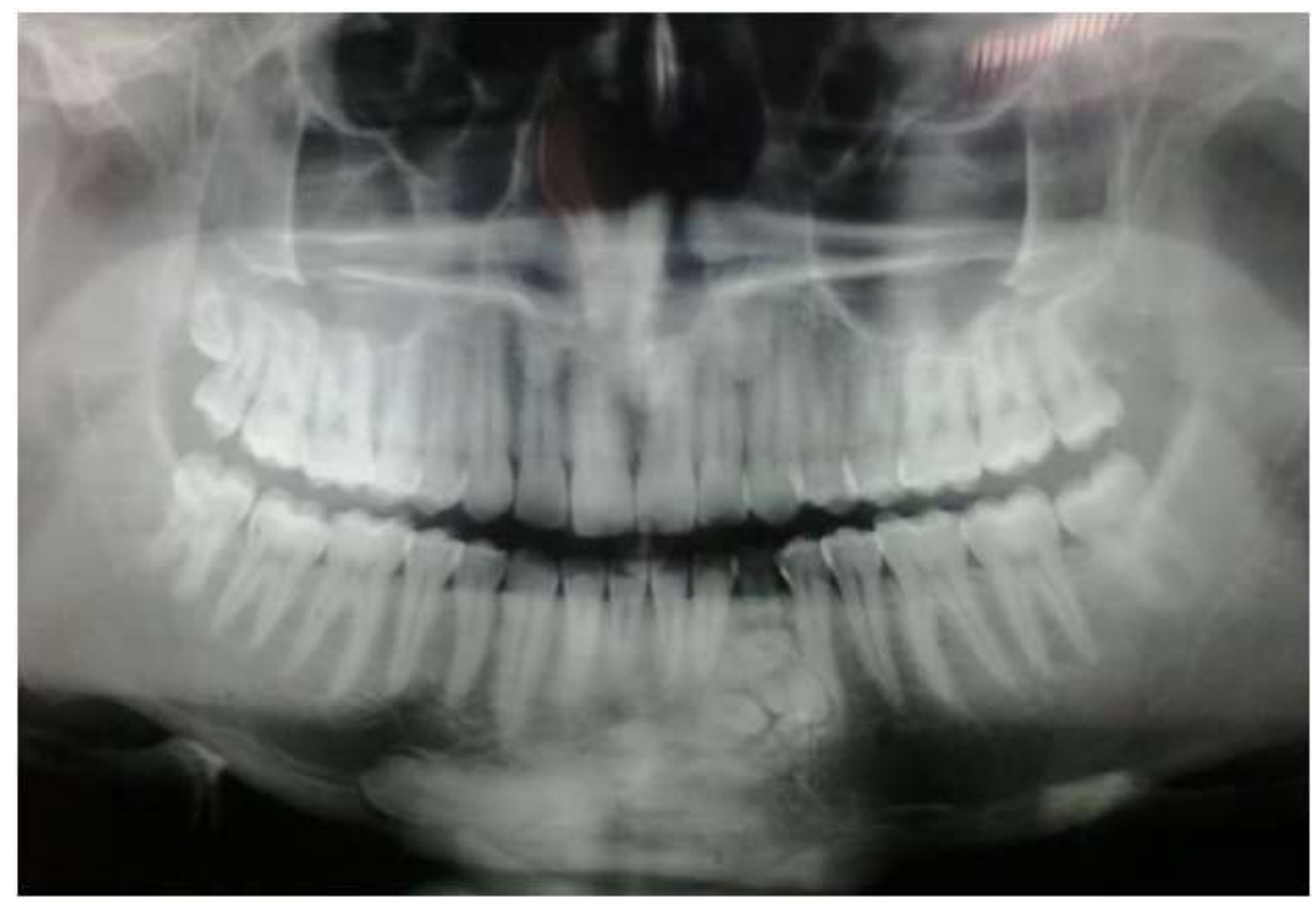

Source: Authors. 
Research, Society and Development, v. 10, n. 13, e50101320987, 2021

(CC BY 4.0) | ISSN 2525-3409 | DOI: http://dx.doi.org/10.33448/rsd-v10i13.20987

Figure 2: Tomographic examination. A: panoramic section; B: Parasagittal section; C: Axial section.
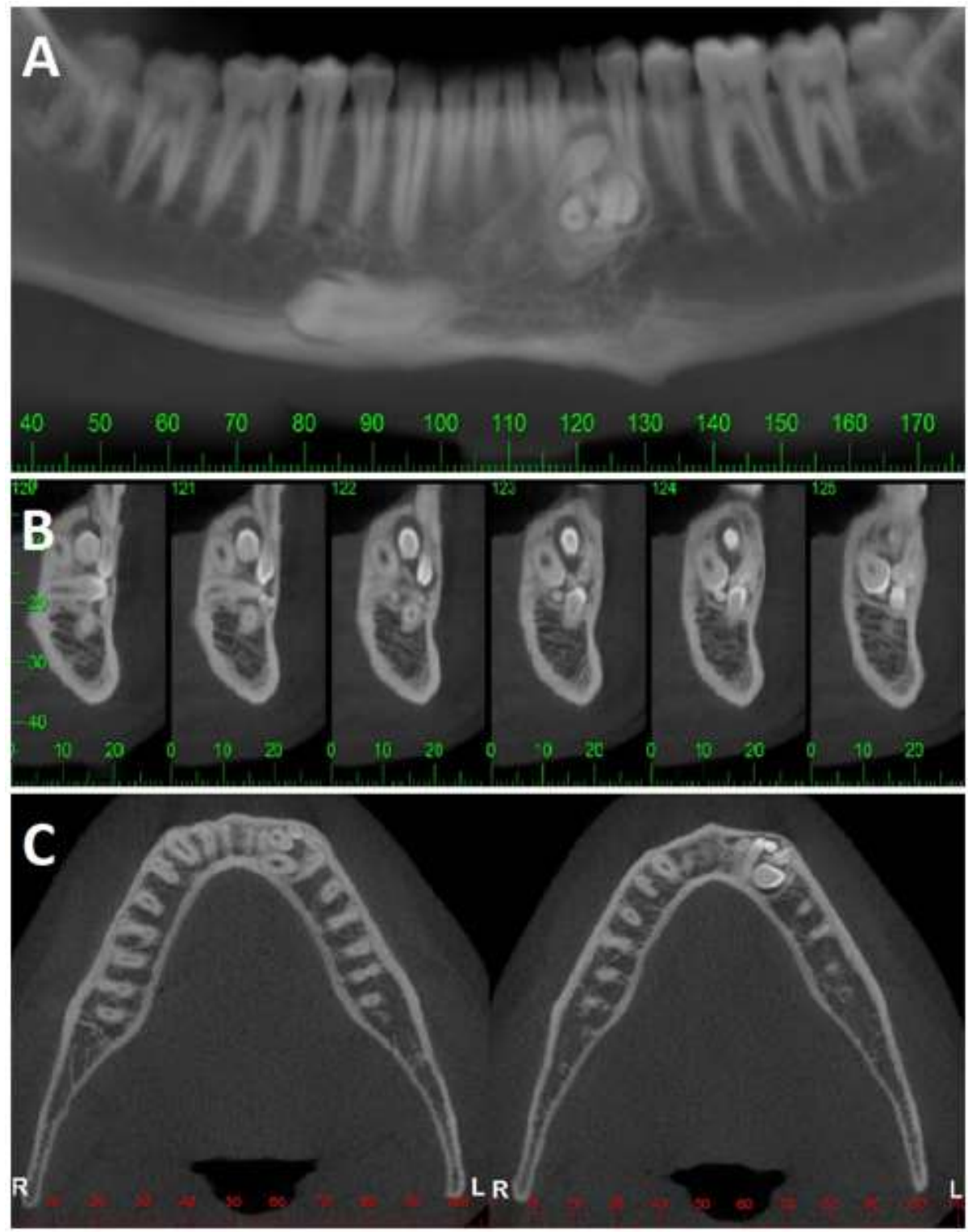

Source: Authors.

Figure 3: Coronal sections showing the extension of the lesion and the different forms, sizes and positioning of the denticles.
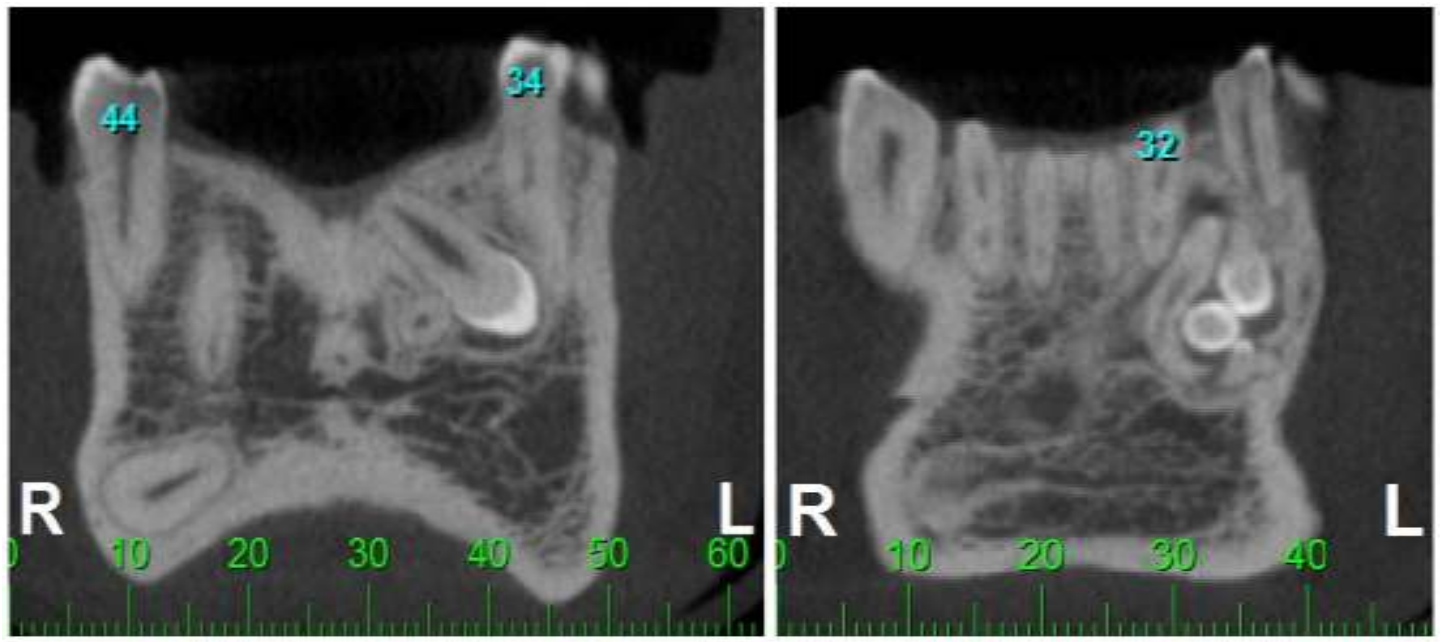

Source: Authors. 
Figure 4: Surgical exposure of the bone tissue and resection of the cortical bone overlying the lesion.

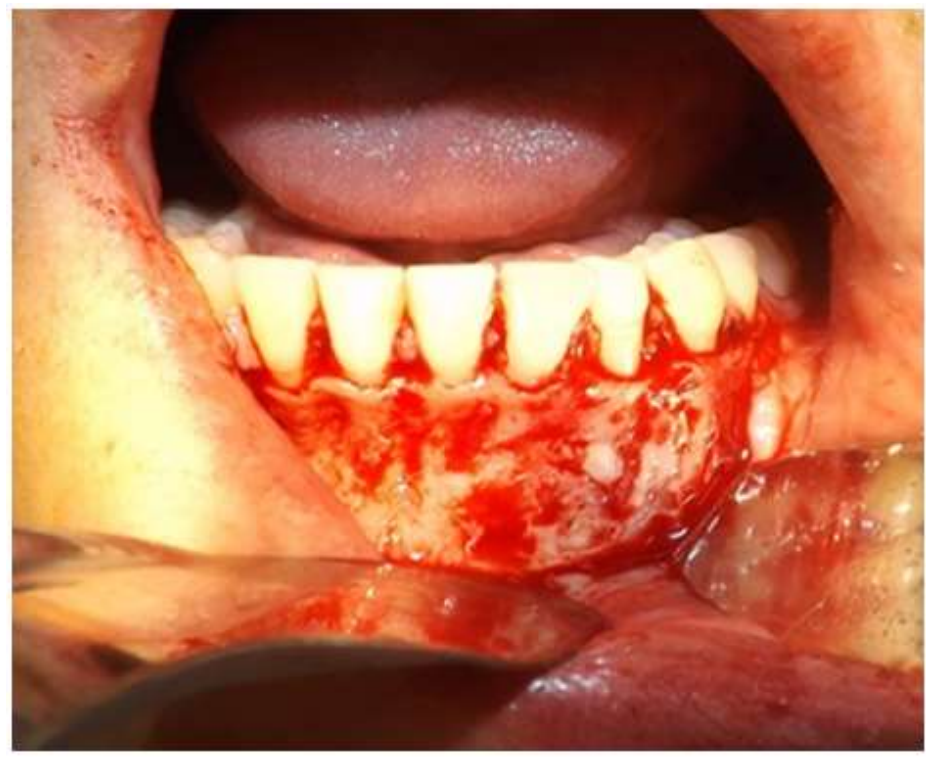

Source: Authors.

Figure 5: Surgical sequence of removal of the odontoma. A: Beginning of the removal of the denticles with the Seldin lever; B: Visualization of the numerous denticles; C: Dislocation of a denticle with a straight extractor; D: Morphology of one of the extracted denticles; E: Odontossection of the crown; F: Removal of the remaining root; G: Aspect of the bone tissue after the surgical debridement of the lesion; H: Suture performed; I: 13 Removed denticles.
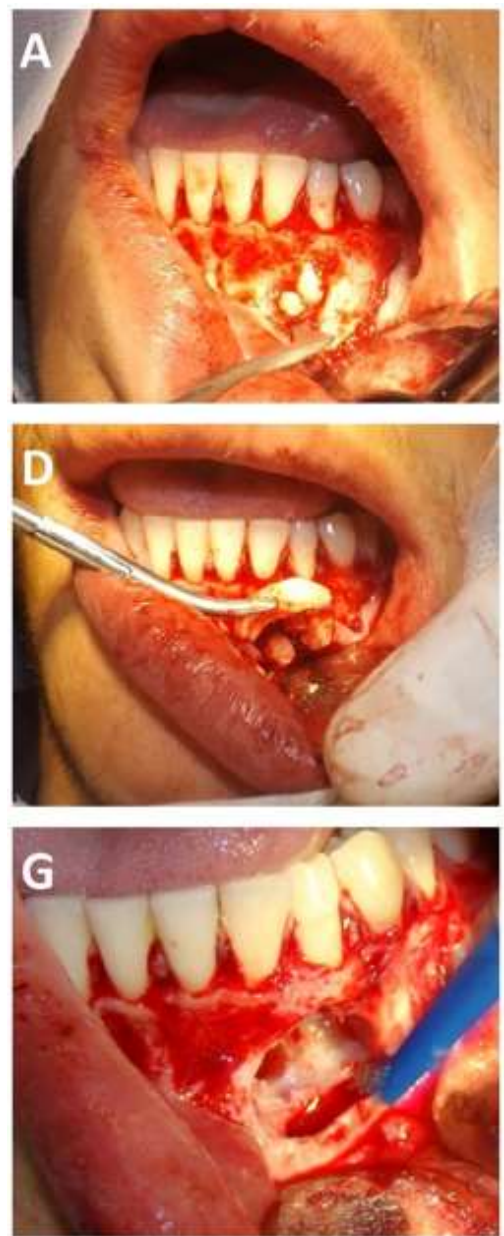
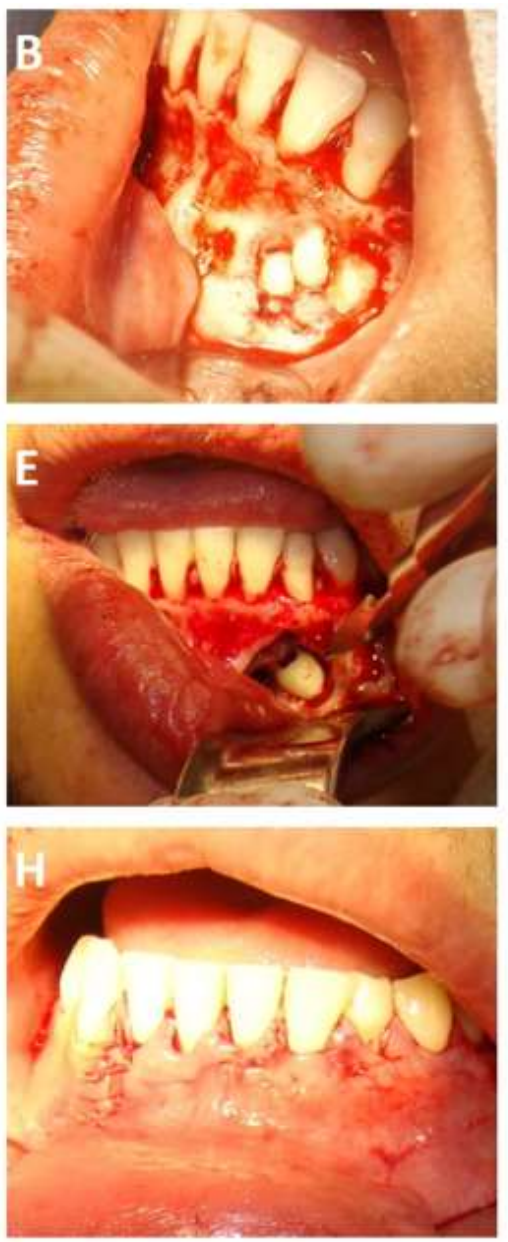

Source: Authors.

6
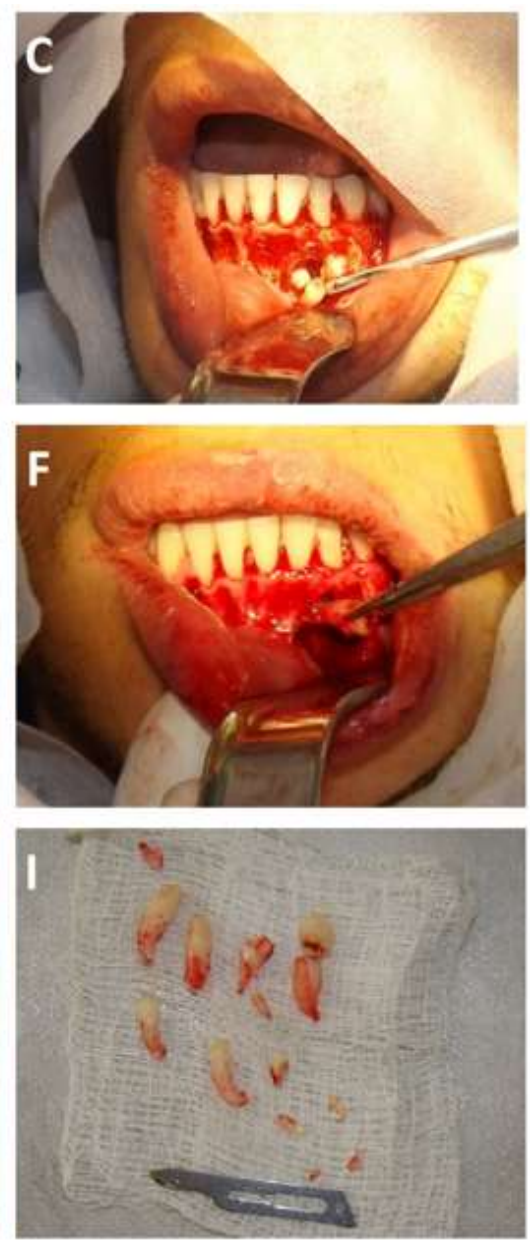
Figure 6: 5-year postoperative. A: Panoramic radiography; B: Parasagittal sections demonstrating the uniqueness of the lesion; C: Coronal sections.
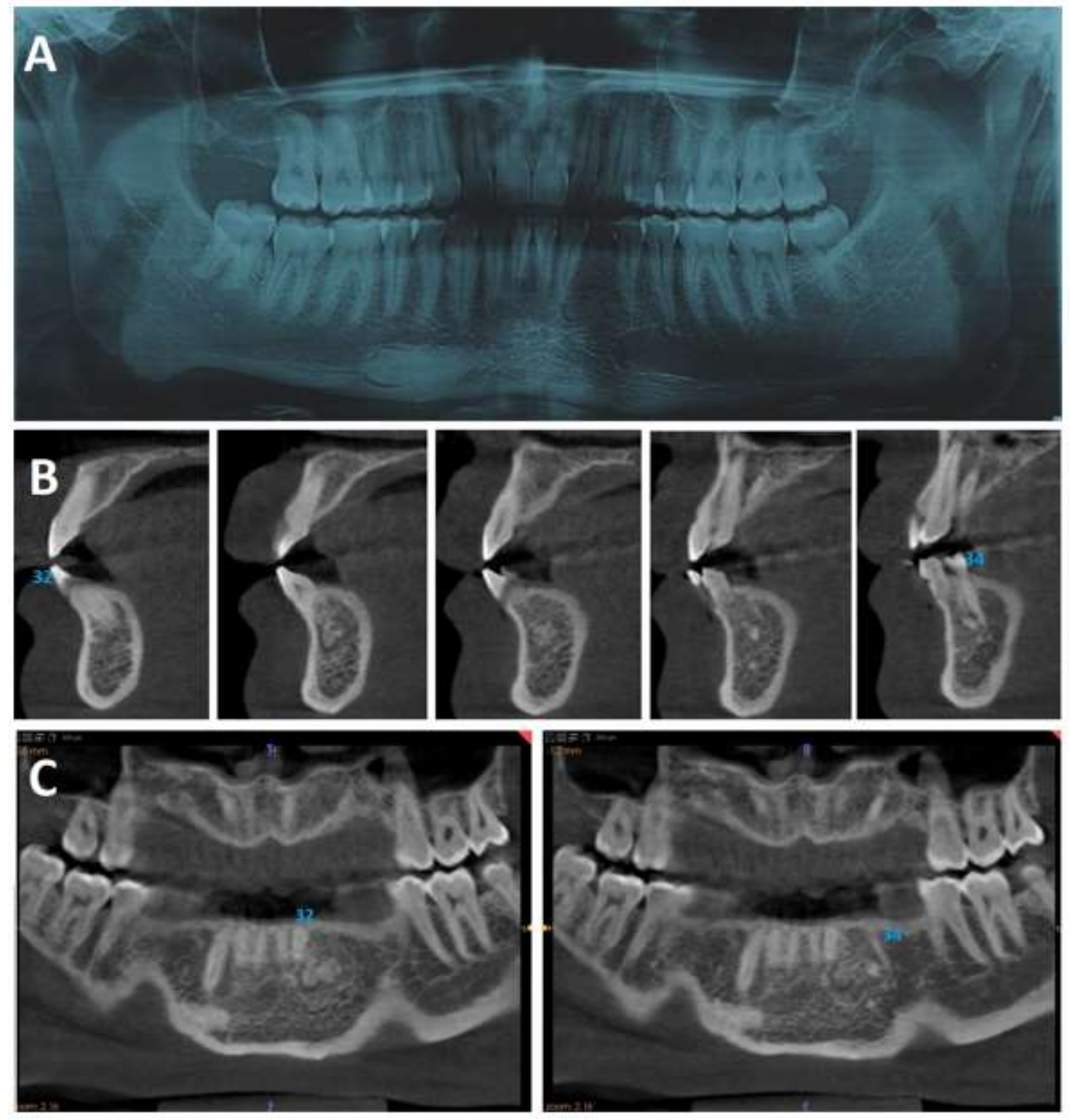

Source: Authors.

\section{Discussion}

Odontomas are conceptualized as malformations or hamartomas in which the epithelial and mesenchymal cells have sufficient differentiation and development to produce enamel and dentin. In addition to classification according to the organization pattern of these tissues, in complex and composite, odontomas can also be classified as central (when inside the bone tissue), peripheral (occurring in maxillary soft tissues) or erupted, according to with its clinical presentation (Katiy ar et al., 2018).

Clinically, it presents as an asymptomatic, non-aggressive lesion with slow growth and benign nature, but may cause some intercurrences; such as interference in the normal eruption of permanent teeth, dental impingement, impossibility of orthodontic treatment, malformation or displacement of neighboring teeth, diastema, anodontia, resorption and dental 
devitalization due to pressure on neighboring teeth, and although rarely observed, facial asymmetry and extra-oral swelling (Jaeger et al., 2012; Jain et al., 2018).

Radiographic examination is essential for the initial diagnosis of the lesion, which, as in the case presented, is usually diagnosed by routine radiographic examinations. The odontomas present a characteristic radiographic appearance, the composite odontoma being characterized by a patognomonic image consisting of 2 or more small denticles. Usually a smooth or irregular well defined peripheral zone with a radiopaque cortical border and an adjacent radiolucent soft tissue capsule can be seen. The internal structure may have small denticles of varying sizes and shapes or, in the case of a complex odontoma, the presence of an ill-defined radiopaque mass with a degree of opacity equivalent to or greater than adjacent structures (Sheehy et al., 2004; Jaeger et al., 2012; Nammalwar et al., 2014).

The treatment of choice for composite odontoma is its surgical removal, since the chances of recurrence of the lesion are very low (Cohen et al., 2004; Kämmerer et al., 2016; Preoteasa et al., 2018). The tomographic examination was of fundamental importance for a more detailed and conservative surgical planning, since it allows visualizing not only the extension of the lesion but also the evaluation of impacted and supernumerary teeth of different planar orientations, as well as in different dimensional reconstructions (Gurler et al., 2017). This surgical approach allowed maintaining the vitality of the neighboring teeth in the operated area, which in the postoperative period of 5 years responded to the pulp vitality test, in addition to preserving to the maximum the buccal bone table. The safety incision, distant from the operated area, would allow primary closure without the need of a bone regeneration procedure, however, a bone substitute of synthetic origin was placed in the surgical site for better adaptation of the soft tissue over the bone tissue.

Although a large part of the literature indicates as minimal the odds of recurrence of odontoma with a resective surgery and no safety margins, we found in a 5-year follow-up of the operated region, radiographic aspects consistent with the bone cortical surrounding the odontoma and small radiopaque areas that appears to be a recurrence tumor or remnant of the lesion near the bone repair region. However, we do not rule out the possibility to be a hypercalcification area or encapsulation of the grafted biomaterial, even though it is a resorbable material. With these findings, we reiterate the importance of long-term follow-up.

\section{Conclusion}

The clinical, radiographic, tomographic and surgical aspects of the lesion are in agreement with the several reports investigated of the occurrence and prevalence of this pathology, although its location shows to vary significantly between the several studies. Surgical removal of the lesion with meticulous debridement of the bone walls should still be considered the approach of choice for odontoma, we emphasize here the importance of periodic follow-up of these patients, even after years of performing the surgical procedure.

\section{References}

Avsever, H., Kurt, H., Suer, T. B., Ozturk, H. P., \& Piskin, B. (2015). The prevalence, anatomic locations and characteristics of the odontomas using panoramic radiographs. Journal of Oral and Maxillofacial Radiology, 3 (2), 49-53.

Budnick, S. D. (1976). Compound and complex odontomas. Oral Surg Oral Med Oral Pathol, 42 (4), 501-506.

Cohen, D. M., \& Bhattacharyya, I. (2004). Ameloblastic fibroma, ameloblastic fibro-odontoma, and odontoma. Oral Maxillofacial Surg Clin North Am, 16 (3), $375-84$.

Gurler, G., Delilbasi, C., \& Delilbasi, E. (2017). Investigation of impacted supernumerary teeth: a cone beam computed tomography (cbct) study. J Istanb Univ Fac Dent, 51(3), 18-24.

Jaeger, F., Alvarenga, R. L., Lage, F. O., Reis, I. A., \& Leal, R. M. (2012). Odontoma composto - relato de caso clínico. Revista Portuguesa de Estomatologia, Medicina Dentária e Cirurgia Maxilofacial, 53 (4), 252-257. 
Research, Society and Development, v. 10, n. 13, e50101320987, 2021

(CC BY 4.0) | ISSN 2525-3409 | DOI: http://dx.doi.org/10.33448/rsd-v10i13.20987

Jain, A., Karuna, Y. M., Baliga, M., Suprabha, B. S., \& Natarajan, S. (2018). Surgical Management of Complex Odontoma Associated with Agenesis of a Molar. Contemp Clin Dent, 9 (2), S388-S390.

Kämmerer, P. W., Schneider, D., Schiegnitz, E., Schneider, S., Walter, C., Frerich, B., \& Kunkel, M. (2016). Clinical parameter of odontoma with special emphasis on treatment of impacted teeth-a retrospective multicentre study and literature review. Clin Oral Investig, 20 (7), 1827-1835.

Kannan, K. S., Prabhakar, R., Saravanan, R., Karthikeyan., \& Rajvikram. (2013). Composite Compound Odontoma-A Case Report. Journal of Clinical and Diagnostic Research, 7 (10), 2406-2407.

Katiyar, A., Gupta, K., Solanki, S., \& Gupta, S. (2018) A case of dental hamartoma associated with unerupted primary canine in maxillary region. Natl J Maxillofac Surg, 9 (2), 232-234.

Matos, A., Castro, B., Rocha, G. R. O. M., Bugarin-Júnior, J. G., Carvalho-Júnior, J. R., \& Oliveira, L. A. (2012). Odontoma composto em região posterior de mandíbula: relato de caso. Oral Sci, 4 (2), 54-58.

Nammalwar, R. B., \& Moses, J. A. (2014). Rare Association of Compound Odontome with Missing Lateral Incisor. Int J Clin Pediatr Dent, 7 (1), $50-53$.

Neville, B. W., Damm, D. D., Allen, C. M., \& Chi, A. C. (2016). Patologia Oral \& Maxilofacial (4a. ed). Elsevier.

Pacifici, A., Carbone, D., Marini, R., \& Pacifici, L. (2015). Surgical Management of Compound Odontoma Associated with Unerupted Tooth. Case Reports in Dentistry, 2015, ID 902618, 6.

Pereira, A. S., Shitsuka, D. M., Parreira, F. J., \& Shitsuka, R. (2018). Methodology of cientific research. UFSM. https://repositorio.ufsm.br/bitstream/handle/1/15824/Lic_Computacao_Metodologia-Pesquisa-Cientifica.pdf?sequence=1\&isAllowed=y.

Preoteasa, C. T., \& Preoteasa, E. (2018). Compound odontoma - morphology, clinical findings and treatment. Case report. Rom J Morphol Embryol, 59 (3), 997-1000.

Raval, N., Mehta, D., Vachhrajani, K., \& Nimavat, A. (2014). Erupted odontoma: A case report. J. Clin. Diagn. Res, 8 (7), ZD10-ZD11.

Salamanca, C., Ottone, N. E., Rubilar, C. A., Garay, I., \& Fuentes, R. (2017). Transmigrated Canines Associated to Odontomas. Int. J. Morphol, 35 (2), $465-$ 468.

Sheehy, E. C., Odell, E. W., \& Al-Jaddir, G. (2004). Odontomas in the primary dentition: literature review and case report. J Dent Child (Chic), 71 (1),73-6.

Silva, N. P., Rodrigues, R. D., Barboza, A. D., Santos, L. C. C., Fialho, P. V., \& Padilha, W. S. M. (2019). Odontoma Composto em Região Anterior de Maxila: Relato de Caso.Brazilian Journal of health Review, 2 (5), 4454-4464.

Silva, C. C. G., Bernardo, B. B. B., Nascimento, V. H. S., Diniz, D. A., Gonçalves, K. K. N., Mendonça, T. L. R., Barros, A. V. M., Silva, P. A., Avelino, M. E. L., \& Laureano Filho, J. R. (2020). Surgical approach to compound odontoma in the jaw. Research, Society and Development, 9 (11), e1499119610. 